\title{
A Study on Determinants of Customer Satisfaction in E-enabled bus booking platforms
}

\author{
Amol Deogadkar1, Dr.Shailendrakumar Kale ${ }^{2}$ \\ ${ }^{1}$ PhD ScholarDr. D.Y. Patil Vidyapeeth, Pune \\ ${ }^{2}$ Professor and Research CoordinatorGlobal Business School \& Research Centre, Dr. D.Y. Patil Vidyapeeth, \\ Pune, ${ }^{1}$ amol.deogadkar@gmail.com
}

\begin{abstract}
Article History: Received: 11 January 2021; Accepted: 27 February 2021; Published online: 5 April 2021
Abstract: E-enabled ventures (especially the online bus booking services) have witnessed impressive growth in India during last decade. Especially after COVID-19, customer shift towards online services is expected to augment. This paper is an attempt to develop a scale for determinants of customer satisfaction amongst the existing users of online bus booking (eenabled platform).Using e-SERVQUAL model by Parasuraman et al. (2005), a draft instrument was designed. Since online bus services also includes physical experience of services offered, Tangibility factor was added in the construct. The questionnaire was tested on a sample of existing users of online bus booking services $(n=105)$. After checking for the adequate reliability score, Exploratory factor Analysis (EFA) was performed. It resulted into extraction of four factors such as Contact, Fulfilment, Privacy and Responsiveness, accounting for 50.5\% of total variance explained. Validating this scale on a larger sample for generalisation of the results would be the future agenda of research. Development of India specific scale for e-enabled business models in public transports can be considered as one of the major contribution of this study. Keywords: E-SERVQUAL, Online bus booking, Privacy, Reliability, e-commerce adoption
\end{abstract}

\section{Introduction}

Indian economy witnessed a digital revolution as the number of wireless connections grew from 601 million to 1144 mn during FY2010 to September 2020, resulting into an impressive teledensity figure of $86 \%$. Moreover, lower cost of internet services and aggressive expansion plans by various companies in e-commerce space has resulted into a matured eco system for e-enabled business models in India. According to the literature, e-enabled business model is a way of doing the business where a product or service is advertised, distributed and exchange of money happens though an electronic gateway.

Due to rapid expansion of e-commerce activities in India, the researcher fraternity started exploring various aspects of online consumer behaviour, adoption intentions and factors inducing a user to continue with any online services used in recent times. Online bus booking is one of the fastest growing sub segment of India's ecommerce industry. Long distances between cities, insufficient supply of government managed bus services and largely unorganised private bus network propelled conception of platforms such as RedBus.com and Makrmytrip.com. Considering the growth opportunity and in quest to avoid revenue sharing with such platforms, bus operators such as Neeta Bus and Khurana Bus services started online booking services through its websites. With rapid urbanisation and requirement of daily commute for work in cities, the demand for such operators in municipal limits has also increased during last five years.

This research is an attempt to explore the determinants of an existing user's satisfaction with online bus booking services. Based on the results of this study, a scale would be developed and tested on a large sample to validate a model of customer satisfaction and generalise results of the study. This model can be considered as the foundation to design futuristic business models of e-enabled bus transport systems. Although, the researchers found evidences of previous investigations into customer satisfaction in bus services or online booking space, majority of these research attempts are in western countries or have limited scope in terms of variables considered in the construct. This research paper is expected contribute significantly to the existing knowledgebase with its India specific scale for customer satisfaction in online bus booking services.

\section{Literature Review}

In the initial stage of this study, the researchers commenced with analysis of base theories and models in ecommerce and focused on constructs used for measuring the customer satisfaction taxonomy in e-enabled business. For the literature review 86 full text peer reviewed research papers were selected from domains such as such as e-retailing, B2B (Business to Business) E-commerce services and C2C (Consumer to Consumer) platforms. Since the intended study concentrates on exploring determinants of customer satisfaction in online bus booking platforms, 63 research papers pertaining to the main theme of the research work were segregated and analysed. The details of literature review and major observations are as follows,

\subsection{Models in Technology Acceptance:}

Davis (1989) presented TAM (Technology Acceptance Model), which is considered as the seminal work in understanding human-technology interactions. According to this theory, Perceived Usefulness (PU) and Perceived Ease of Use (PEOU) acts as determinants of a user's attitude to accept a particular technology. Attitude in tune, impacts a person's behavioural intensions. Venkatesh et al. (2003) presented Unified Theory of Acceptance and usage of Technology (UTAUT) by assimilating the construct of eight previous models proposed for technology adoption and tested this newly developed framework to explore better predictability of the 
behavioural intensions. According to theory, four determinants of the behavioural intensions (performance expectancy, effort expectancy, social influence \& facilitating conditions) were proposed. Four factors such as age, gender, experience and voluntariness of use were proposed to have a moderating impact on relationship between four determinants and behavioural intensions.

\subsection{Models for measuring online/offline customer satisfaction:}

According to Oliver (1997) customer satisfaction can be defined as "the consumer's fulfilment response. It is a judgment that a product or servicefeature, or the product of service itself, provided (or is providing) a pleasurable level ofconsumption-related fulfilment, including levels of under- or over-fulfilment" This definition considers consumption related perceived feeling of fulfilment, which a user seeking. Importantly, the focus of this definition is on consumer rather than the customer (who actually pays for the product or services).

Woodruff and Gardial (1996) presented a traditional macro-model of customer satisfaction which states that, perceived performance and comparison standards do impact Perceived Disconfirmation, which is a simple performance evaluation according to some set standards. This Perceived Disconfirmation has a direct impact on feeling of satisfaction. Oliver (1999) devised an input-satisfaction-output model, which theorised that, quality, performance outcomes and cost based value acts as antecedents of customer satisfaction, leading to three outcomes such as consumption value, extended value and value based satisfaction.

\section{SERVQUAL:}

SERVQUAL, the Seminal work by Parasuraman et al. $(1985,88)$ pioneered the service quality framework with introduction of quality attributes concept and 10 different dimensions of service quality to measure the gap in expected and actual service quality delivered. Parasuraman et al. (1994) reduced the constructed to a five dimensional model for measuring service quality. These five dimensions are discussed as below

- Tangibles: It involves all the physical attributes related with service delivery and includes physical facilities, equipment and appearance and mannerism of the person who delivers the services.

- Reliability: It is the capacity to perform or deliver promised services accurately and how dependable (sure) a user can be, when it comes to service delivery

- Responsiveness:It's the willingness of a service provider to help customers in case of any problem or discomfort and provide a prompt service.

- Assurance: It is the capacity or skill of employees to extend courtesy to the user and ability to inspire trust and confidence about service assurance.

- Empathy: The feeling of 'every user matters' or a service oriented approach to serve each and every customer with caring and individualized attention.

\section{E-SERVQUAL:}

Taking a base of SERVQUAL model, Zeithaml et al. $(2001,2002)$ introduced the e-SERVQUAL to measure e-service quality and discussed the process by which a customer judges e-service quality and related aspects. According to these researches, core scale (with 4 dimensions) and recovery scale (with 3 dimensions) were formulated. Core scales are related with actual service delivery and recovery scale includes variables which are considered, only when a user encounters any problem from the online services.

Core Scale Dimensions:

The dimensions included in core scale are as follows,

- Efficiency:The ease at which a customer or user can find /access information related with the website or products /services and all relevant information.

- Fulfilment: accuracy of service requirements, availability of the product in storage, and delivering the products on time

- Reliability: The correctness of technical specification and how minutely the web platform is functioning properly in terms of speed and navigation.

- Privacy: an assurance about keeping personal and financial data of users safe.

Recovery Scale Dimensions:

- Responsiveness: ability of the service provider to handle query, give correct information to the user, in case of any problem and faster, efficient return mechanism in case of wrong or incomplete delivery.

- Contact: availability of a system where a user can easily interact and talk to a live person to handle his/her problem.

- Compensation:capacity to compensate the users either with money refund or appropriate alternative adjustments, which are equal in value.

\subsection{Studies based on E-SERVQUAL:}

The researchers studied various previous investigations on application of E-SERVQUAL model in various services and geographic contexts. The summary of analysis is as follows, 
Raza et al. (2020) studied the service quality dimensions in Internet banking and their impact one-customer's satisfaction and e-customer's loyalty in context of Pakistani users. The study used a modified construct by adding variables such as user friendliness and personal needs to originals E-SERVQUAL constructs such as responsiveness, reliability and efficiency. It was observed that, all proposed determinants have a direct and positive impact on electronic customer satisfaction, which in tune results into customer loyalty.

Ting et al. (2016) studied interplay of e-service quality perception, e-satisfaction and e-loyalty in case of Malaysian online shoppers. The study considered a multi-dimensional construct by bringing together efficiency, fulfilment, reliability of E-SERVQUAL, web design from e-TailQ and considered privacy and trust as a single variable to measure e-service quality in B2C (Business to Consumer) space. All the proposed determinants were found to have statistically significant impact on e-service quality perception of a user. Out of all the predictors, responsiveness and efficiency were found to have maximum contribution to variance explained.

\subsection{Studies on service quality in bus transport services:}

Mashur (2019) studied the impact of e-CRM (Customer Relationship Management), e-service quality on ecustomer satisfaction and e-loyalty. The results obtained from a sample of 167 users of online bus booking services indicates that, e-service quality has a significant impact on both, customer loyalty and satisfaction.

Valenzo-Jiménez et al. (2019) conducted a study to evaluate the quality of the public transportation system service in the city of Morelia, Mexico. SERVQUAL model with five dimensions was applied on a sample of 392 respondents with 15 years of average experience in using bus transport systems. Findings show medium level of perceived quality and a high gapbetween the expected and the received service, which has a direct impact on esatisfaction of a user.

\section{Conceptual Framework:}

Based on E-SERVQUAL model by Parasuraman et al. (2005) and one construct adopted from SERVQUAL model, conceptualised framework for determinants of customer satisfaction amongst users of online bus booking services was developed. Eight dimensions such as Efficiency (EFF), Fulfilment (FUL), Privacy (PRV), Responsiveness (RSP), Compensation (COM), Contact (CON), Reliability (REL) and Tangible (TAN) are proposed to act as determinant of a user's satisfaction. The proposed framework is presented as Figure 1.

Figure 1: Conceptual Framework (research model):

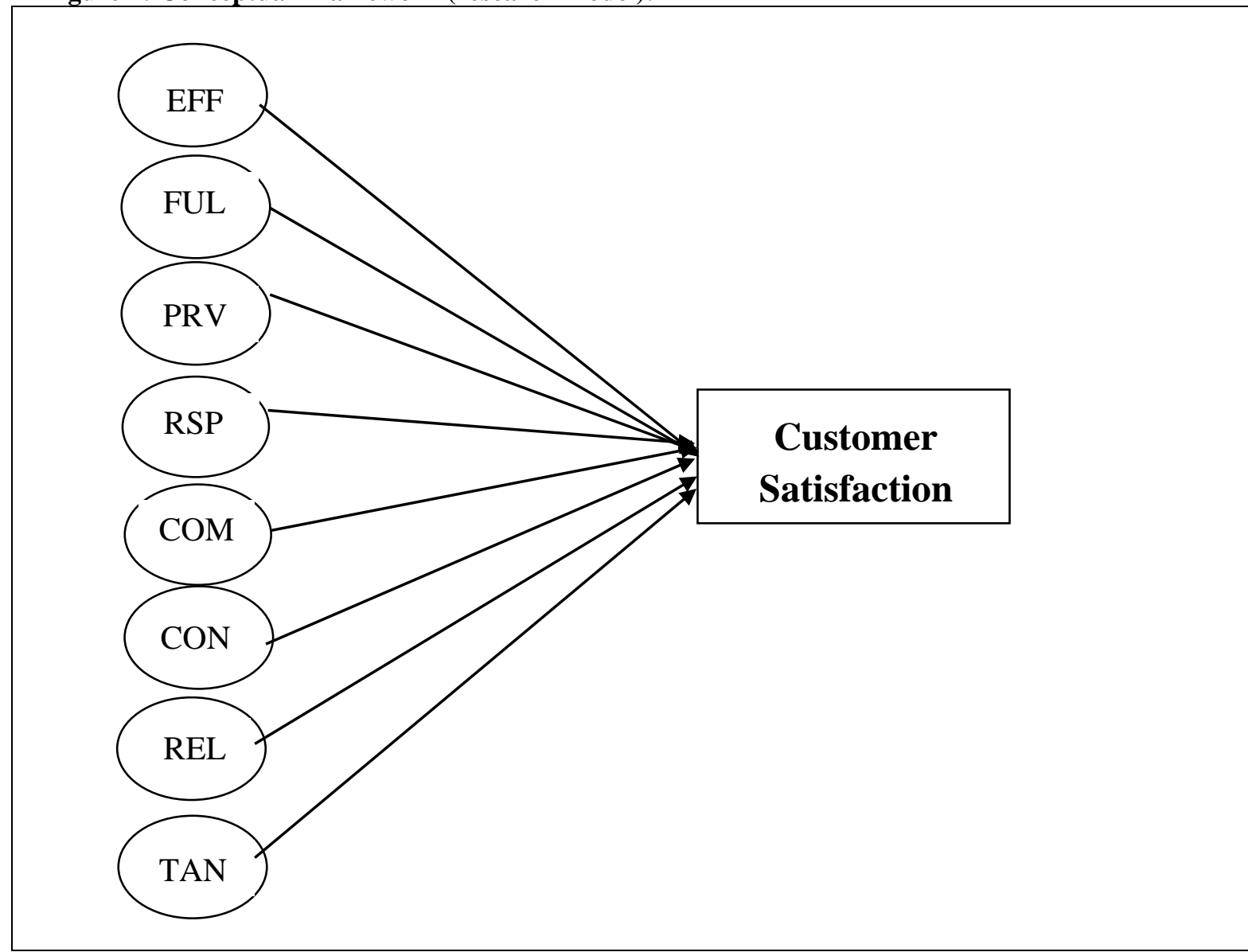

EFF: Efficiency, FUL: Fulfilment, PRV: Privacy, RSP: Responsiveness, COM= Compensation 
CON: Contact, REL: Reliability, TAN: Tangible

\section{Objectives and Hypotheses}

The study aims at finding out factors acting as determinants of customer satisfaction amongst the users of online bus booking services in India. The specific objectives of the research are as follows,

\section{Objective 1: To study validated e-satisfaction scales from the past studies}

Objective 2: To conceptualise a research framework and to develop a scale for measuring e-satisfaction amongst the existing users of the online bus booking services.

Based on the conceptual framework, draft hypotheses are formulated as below,

H1: Efficiency (EFF) has direct impact on customer satisfaction of online bus booking services.

H2: Fulfilment (FUL) has direct impact on customer satisfaction of online bus booking services.

H3: Privacy (PRV) has direct impact on customer satisfaction of online bus booking services.

H4: Responsiveness (RSP) has direct impact on customer satisfaction of online bus booking services.

H5: Compensation (COM) has direct impact on customer satisfaction of online bus booking services.

H6: Contact (CON) has direct impact on customer satisfaction of online bus booking services.

H7: Tangible Factor (TAN) has direct impact on customer satisfaction of online bus booking services.

\section{Research Methodology}

Research Methodology is a systematic approach adopted by the researcher to study a particular phenomenon and seek logical validation of previously prescribed models and theories. The intended research activity wishes to find out the determinants of customer satisfaction amongst users of online bus booking services. By using non-probability convenience sampling method, a sample 112 respondents was drawn from the existing users of online bus booking services, falling in the age group of 18-35. Adequate representation of all demographic factors (age, sex, occupation and frequency of online bus booking) was ensured. The instrument used for data collection and its development procedure is discussed under subsequent heading.

\section{Instrument Development Process}

A critical analysis of literature review provides us evidence of various scales used for conducting research on variables identified. However, for the process of instrument development, studies concentrating on measuring eservice quality were considered and scales validated by each of these empirical researches were collated together. Scales validated by Some of the studies such as Kostrzewska\&Wrukowska (2019), Mouakket\& AlHawari (2012), Parsuraman et al. (2005), Zavareh et al. (2012), Randheer et al. (2011), Muthupandian\&Vijayakumar (2012) and Huang (2010) were considered for item pooling. Some contextual customisation in the wording of the items was done to ensure that, the instrument would be able to capture right attributes of customer behaviour and perceptions of the targeted population.

In order to achieve face and content validity, the draft instrument was sent to five researchers (3academicians from online customer behaviour domain and 2 practicing executives working on customer centricity models in ebusinesses). This activity was completely on voluntary basis and no remuneration was paid to the experts for their advice. Experts were briefed about the objectives of the said study and the rationale behind selecting specific variables. Based on the expert's opinion, necessary changes in the draft instrument were carried and after converting it into an online questionnaire, it was circulated amongst the targeted population group.

Conceptualised scale:Based on the construct of E-SERVQUAL and Tangible dimension used in SERVQUAL model, a draft questionnaire of 41 items pertaining to 9 variables was prepared. The scale and determinant-wise count is shown as Table 1 
Table 1: Proposed Scale and determinants

\begin{tabular}{|c|c|c|}
\hline Sr. & Variable & No. Of Items \\
\hline 1 & Efficiency & 5 \\
\hline 2 & Fulfilment & 5 \\
\hline 3 & Privacy & 5 \\
\hline 4 & Response & 4 \\
\hline 5 & Compensation & 4 \\
\hline 6 & Contact & 5 \\
\hline 7 & Reliability & 4 \\
\hline 8 & Tangibility & 5 \\
\hline 9 & Satisfaction & 4 \\
\hline & Total Items & $\mathbf{4 1}$ \\
\hline
\end{tabular}

\section{Data Analysis}

The sample size for pilot study was selected in such a manner that, it would have adequate representation of the target population. Data was collected from 112 respondents (having prior experience of online bus booking). 7 entries were dropped due to incomplete data and entries by 105 respondents were considered for the analysis. Out of the total respondents, $53.3 \%$ are male, and 59\% of the respondents fall in 18 to 22 age bracket. 59\% are students, followed by working professionals (36\%). 64\% of the respondents book 5 to 10 tickets per year. $35 \%$ of the respondents are availing online bus booking services for the period of 1-2 years while $31 \%$ have less than one year of experience in online bus booking.

Table 2: Demographics of the Sample respondents $(n=105)$

\begin{tabular}{|c|c|c|c|c|}
\hline Parameter & \multicolumn{2}{|c|}{ Numbers } & \multicolumn{2}{|c|}{ Percentage } \\
\hline \multirow{3}{*}{ Gender } & Male & 56 & Male & $53.3 \%$ \\
\hline & Female & 49 & Female & $46.7 \%$ \\
\hline & Total & 105 & Total & $100 \%$ \\
\hline \multirow{4}{*}{ Age Group } & 18 to 22 & 62 & 18 to 22 & $59 \%$ \\
\hline & 23 to 27 & 23 & 23 to 27 & $22 \%$ \\
\hline & 28 to 35 & 20 & 28 to 35 & $19 \%$ \\
\hline & Total & 105 & Total & $100 \%$ \\
\hline \multirow{4}{*}{ Profession } & Student & 62 & Student & $59 \%$ \\
\hline & Self Employed & 5 & Self Employed & $5 \%$ \\
\hline & $\begin{array}{r}\text { Working } \\
\text { professional }\end{array}$ & 38 & $\begin{array}{r}\text { Working } \\
\text { professional }\end{array}$ & $36 \%$ \\
\hline & Total & 105 & Total & $100 \%$ \\
\hline \multirow{4}{*}{$\begin{array}{c}\text { Yearly } \\
\text { Booking } \\
\text { Frequency }\end{array}$} & Rarely & 8 & Rarely & $8 \%$ \\
\hline & 5 to 10 times & 67 & 5 to 10 times & $64 \%$ \\
\hline & More than 10 times & 30 & More than 10 times & $29 \%$ \\
\hline & Total & 105 & Total & $100 \%$ \\
\hline \multirow{5}{*}{$\begin{array}{l}\text { Online bus } \\
\text { booking } \\
\text { experience }\end{array}$} & Less than a year & 33 & Less than a year & $31 \%$ \\
\hline & 1 to 2 years & 37 & 1 to 2 years & $35 \%$ \\
\hline & 2 to 3 years & 21 & 2 to 3 years & $20 \%$ \\
\hline & More than 3 years & 14 & More than 3 years & $13 \%$ \\
\hline & Total & 105 & Total & $100 \%$ \\
\hline
\end{tabular}




\begin{tabular}{|c|c|c|c|c|}
\hline \multirow{3}{*}{$\begin{array}{c}\text { Preferred } \\
\text { website }\end{array}$} & Redbus & 78 & Redbus & $74 \%$ \\
\cline { 2 - 5 } & Makemytrip & 63 & Makemytrip & $60 \%$ \\
\cline { 2 - 5 } & PayTM & 51 & PayTM & $49 \%$ \\
\hline
\end{tabular}

\subsection{Reliability Analysis:}

Peter (1979) defines Reliability as 'the degree to which measures are free from error and therefore yield consistent results'. Reliability analysis is an important step to be carried out before undertaking any further data analysis process. The index of Reliability, which is popularly known as Cronbach's Alpha was introduced by Cronbach (1951). As a thumb rule, reliability score above 0.7 is considered to be ideal. However, according to some researches such as Hair et al. (2019), reliability score above 0.95 indicates data redundancy. The initial results of construct-wise reliability for 42 items indicated that, the Reliability construct has below par reliability score (0.493) similarly, three other items from two constructs reported unacceptable reliability score. As a result, 8 items were dropped from the instrument. The questionnaire with34 items and 105 respondents, the overall reliability stood at 0.93 which is higher than the threshold limits (0.7 and above) prescribed by Nunally (1967). These results indicates suitability of the instrument for larger size data collection and analysis.

Table 3: Construct wise reliability

\begin{tabular}{|r|c|c|c|}
\hline $\begin{array}{r}\text { S } \\
\text { r. }\end{array}$ & Variable & Reliability & $\begin{array}{c}\text { No of } \\
\text { items }\end{array}$ \\
\hline 1 & Efficiency & 0.606 & 5 \\
\hline 2 & Fulfilment & 0.695 & 4 \\
\hline 3 & Privacy & 0.614 & 4 \\
\hline 4 & Response & 0.628 & 4 \\
\hline 5 & Compensation & 0.663 & 4 \\
\hline 6 & Contact & 0.822 & 5 \\
\hline 7 & Tangibility & 0.652 & 4 \\
\hline 8 & Satisfaction & 0.624 & 4 \\
\hline \multicolumn{2}{|c|}{ Overall Reliability score } & $\mathbf{0 . 9 3}$ \\
\hline
\end{tabular}

Construct wise reliability is an indication of goodness of the item wise reliability under each construct. All the constructs reported reliability score of above 0.6 , which can be considered as decent for running EFA (Exploratory Factor Analysis) and unearth the latent structure underlying the dataset.

\subsection{Exploratory Factor Analysis (EFA):}

Exploratory factor analysis is performed to regroup factors into smaller set of summary variables and to study the factor structure underlying the data collected. Under Principal Component factor analysis method, the system chooses factors which explains maximum variance, thereby, the researcher can focus on factors having maximum impact on the causal model.

For factor extraction, sevenindependent variables with 30 corresponding items were considered. Factor analysis, using Varimax rotation was applied to arrive at the factor structure. KMO (Kaiser Meyer Olkin Measure of Sampling Adequacy) is used as a measure of adequacy. This indicator tells us the common variance amongst the variables included in the study. KMO value is presented in the range of 0 to 1 . As per Cemiand Kaiser (1977), KMO value between 0.5 and 1 is considered to be appropriate for further analysis. The results of $\mathrm{KMO}$ test and factor analysis are as follows,

Table 4: KMO Results

KMO and Bartlett's Test

\begin{tabular}{|l|l|r|}
\hline \multicolumn{2}{|c|}{ KMO and Bartlett's Test } \\
\hline Kaiser-Meyer-Olkin Measure of Sampling Adequacy. & 0.838 \\
\hline Bartlett's Test of Sphericity & Approx. Chi-Square & 1846.8 \\
& & \\
\cline { 2 - 3 } & Df & 435 \\
\cline { 2 - 3 } & Sig. & 0.000 \\
\hline
\end{tabular}

The KMO indicator for the study stands at 0.838 , which is within acceptable range as per Cemi and Kaiser (1977). Bartlett's test of Sphercity is a measure to prove a significant relationship among the variables considered under the study. According to this indicator, value of significance below 0.05 is considered to be the 
fit (Pavlou; 2007). As the data analysis indicates Bartlettes Test of Sphericity value as 0.00, data is suitable for statistical analysis.

Table 5: EFA Results

\begin{tabular}{|c|c|c|c|c|c|c|c|c|c|}
\hline \multicolumn{10}{|c|}{ Total Variance Explained } \\
\hline & \multicolumn{3}{|c|}{ Initial Eigenvalues } & \multicolumn{3}{|c|}{$\begin{array}{l}\text { Extraction Sums of } \\
\text { Squared Loadings }\end{array}$} & \multicolumn{3}{|c|}{$\begin{array}{l}\text { Rotation Sums of } \\
\text { Squared Loadings }\end{array}$} \\
\hline $\mathrm{mp}$ & $\begin{array}{l}\text { Tot } \\
\text { al }\end{array}$ & $\begin{array}{c}\% \\
\text { of } \\
\text { Varian } \\
\text { ce }\end{array}$ & $\begin{array}{r}\mathrm{Cu} \\
\text { mulati } \\
\text { ve } \%\end{array}$ & $\begin{array}{l}\text { Tot } \\
\text { al }\end{array}$ & $\begin{array}{c}\% \\
\text { of } \\
\text { Varian } \\
\text { ce }\end{array}$ & $\begin{array}{r}\mathrm{Cu} \\
\text { mulati } \\
\text { ve } \%\end{array}$ & $\begin{array}{l}\text { Tot } \\
\text { al }\end{array}$ & $\begin{array}{c}\% \\
\text { of } \\
\text { Varian } \\
\text { ce } \\
\end{array}$ & $\begin{array}{r}\mathrm{Cu} \\
\text { mulati } \\
\text { ve } \%\end{array}$ \\
\hline 1 & 10. & 35. & 35. & 10. & 35. & 35. & 6.3 & 21. & 21 \\
\hline 2 & 2.3 & 7.7 & 42. & 2.3 & 7.7 & 42. & 3.9 & 13. & 34 \\
\hline 3 & 1.9 & 6.5 & 49. & 1.9 & 6.5 & 49. & 2.5 & 8.5 & 42 \\
\hline 4 & 1.7 & 5.6 & 54. & 1.7 & 5.6 & 54. & 2.4 & 8.0 & 50 \\
\hline
\end{tabular}

Based on the EFA results, four factors were extracted, accounting for $50.5 \%$ of the total variance. Although, the initial extraction fetched 6 factors, the last two factors couldn't meet the criteria of minimum three items above 0.6 rotated loading. As a result, these two factors were dropped. Details about four factors emerging out of the process are as follows,

Factor 1: Contact (CON): In line with previous studies on E-SERVQUAL, this research found Contact as one of the emerging factor from EFA process with maximum contribution $(21 \%)$ to the total variance explained. Contact refers toall information points a user needs during the entire process of online bus booking and delivery experience. It includes information availability on the website/app, updates related with bus location or easy access to information, in case of any problem with the payment or booking errors.

Factor 2: Fulfilment (FUL) -It refers to completion of the service promises made by the service provider and includes fulfilment of agreed service deliverables, punctuality of the bus schedule. One item from responsiveness (ability to take quick actionon any negative feedback posted on social media) got merged with this factor. It indicates that, the users perceive e-platform's promptness to take care of concerns raised on social media, as a part of fulfilment of service standards promised. This factor contributes $13.1 \%$ variance.

Factor 3: Privacy (PRV)-Similar to previous studies such as, Kostrzewska\&Wrukowska (2019) and Zavareh (2012), privacy dimension was extracted through EFA. Especially in online consumer behaviour, a user's concerns about potential misuse of data or financial information are considered under this factor. It stands as the third largest factor and contributes $8.5 \%$ to the total variance explained.

Factor 4: Responsiveness (RSP)-Responsiveness is the capacity of a system to handle customer's problems arising out of wrong payment or incomplete transaction despite deduction of the payment from user's account. In such cases, how quick and responsive is the system to handle such issues? Is the user getting adequate information without much hassle and is the platform concerned enough to take care of user's suggestions? These all factors are considered under responsiveness. It contributes $8.0 \%$ to the total variance explained.

Item loading for each of the factor extracted and variance explained by individual factor is presented in Appendix.

\section{Conclusions and Discussions:}

This research paper aimed at developing and validating a scale for customer satisfaction amongst users of online bus booking platforms. Based on E-SERVQUAL model, a draft questionnaire was designed and tested on a sample of 105 respondents. After removing items with lower reliability scores, the overall instrument reliability stood at 0.93 , well above the prescribed threshold of 0.7 by Nunnaly (1967). Using exploratory factor analysis with Principal Component method and Varimax rotation, four factors were extracted which accounts for 50.2\% of the total variance explained. According to the revised framework, Contact, Fulfilment, Privacy and Responsiveness are proposed as determinants of a user's customer satisfaction in online bus booking platforms.

Detailed analysis of EFA indicates that, the Reliability construct reported miniscule reliability score and was dropped from the further analysis. These results are in contradiction with the original E-SERVQUAL model, which considers this dimension as one of the core scales. These results may be attributed to the fact that, the entire respondents group belongs to sub 35 age group and may have different perceived reliability concepts, compared with their older counterparts. 
Figure 2:Revised Conceptual Framework

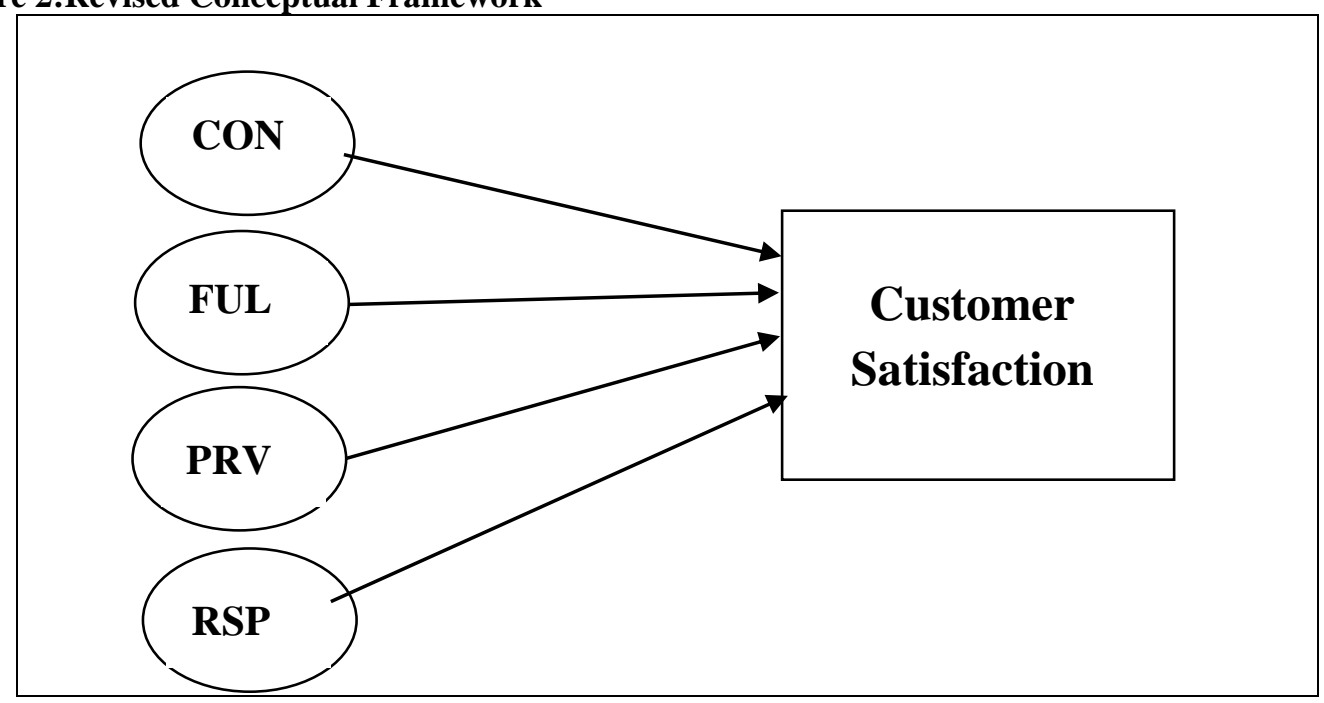

The revised conceptual framework theorises that, Contact (CON), Fulfilment (FUL), Privacy (PRV) and Responsiveness (RSP) act as determinants of customer satisfaction amongst the users of online bus booking platforms. The revised conceptual framework would be testedon a larger set of respondents, to check the model fit and generalisation of the findings. Since online bus booking involves a physical customer experience 'Tangible' dimension was added to the E-SERVQUAL construct. This has resulted into a broad based construct and the validated model can serve as the foundation for further investigations into this domain.

\section{References and Citations}

1. Parasuraman, A. Zeithaml, V, Malhotra A,(2005). E-S-QUAL, A Multiple-Item Scale for AssessingElectronic Service Quality; Journal of Service Research,7(3), 213-233

2. Bartlett MS. Tests of significance in factor analysis. British Journal of Psychology.1950;3(Part II):77-85.

3. Cerny, C.A., \& Kaiser, H.F. (1977). A study of a measure of sampling adequacy for factor-analytic correlation matrices. Multivariate Behavioral Research, 12(1), 43-47

4. Cronbach, L. J. (1951). Coefficient alpha and the internal structure of tests. psychometrika, 16(3), 297-334.

5. Davis, F. D. "Perceived Usefulness, Perceived Ease of Use, and User Acceptance of Information Technology," MIS Quarterly (13:3), 1989, pp. 319-339.

6. Venkatesh, V., Morris, M.G., Davis, G.B., and Davis, F.D. User acceptance of information technology: toward a unified view, MIS Quarterly 27(3), 2003, pp.425-478

7. Oliver, R. Satisfaction: A Behavioral Perspective on the Consumer. Boston: McGraw-Hill, 1997

8. Oliver, R. "Value as Excellence in the Consumption Experience." In M. Holbrook (Ed.), Consumer Value: A Framework for Analysis and Research, 43-62, New York: Routledge, 1999.

9. Parasuraman, A., Zeithaml, V. A., \& Berry, L. L. (1985). A conceptual model of service quality and its implications for future research. The Journal of Marketing, 49, $41-50$

10. Parasuraman, A., Zeithaml, V. A., \& Berry, L. L. (1988). Servqual. Journal of Retailing, 64(1), 12 -40. Parasuraman, A., Zeithaml, V. A., \& Berry, L. L. (1994). Alternative scales for measuring service quality: A comparative assessment based on psychometric and diagnostic criteria. Journal of Retailing, 70(3), 201 230

11. Raza, S. A., Umer, A., Qureshi, M. A., \&Dahri, A. S. (2020). Internet banking service quality, e-customer satisfaction and loyalty: the modified e-SERVQUAL model. The TQM Journal.

12. Zeithaml, V.A., Parasuraman, A., \& Malhotra, A. (2001). A conceptual framework for understanding eservice quality: Implication for future research and managerial practice. MSI Working Paper Series, No. 00115. Cambridge, MA.

a. Zeithaml, V.A., Parasuraman, A., \& Malhotra, A. (2002). Service quality delivery through web sites: A critical review of extant knowledge. Journal of the Academy of Marketing Science, 30(4), 362- 375.

13. Ting, O. S., Ariff, M. S. M., Zakuan, N., Sulaiman, Z., \& Saman, M. Z. M. (2016, May). E-service quality, e-satisfaction and e-loyalty of online shoppers in business to consumer market; Evidence form Malaysia. In IOP Conference Series: Materials Science and Engineering (Vol. 131, No. 1, p. 012012). IOP Publishing. 
14. MASHUR, R., GUNAWAN, B. I., FITRIANY, F., ASHOER, M., HIDAYAT, M., \& ADITYA, H. P. K. P. (2019). Moving from traditional to society 5.0: Case study by online transportation business. The Journal of Distribution Science, 17(9), 93-102.

15. Valenzo-Jiménez, M. A., Lazaro-López, D. A., \& Martínez-Arroyo, J. A. (2019). Application of the SERVQUAL model to evaluate the quality in the transportation service in Morelia, Mexico. Dyna, 86(211), 64.

16. Hair, J. F., Risher, J. J., Sarstedt, M., \&Ringle, C. M. (2019). When to use and how to report the results of PLS-SEM. European Business Review.31 (1), 2-24.

17. Kostrzewska, M., \&Wrukowska, D. (2019). Measuring customer satisfaction in the e-service market.Advances in Business-Related Scientific Research Journal, Volume 10, No. 2, 2019

18. Mouakket, S., \& Al-hawari, M. A. (2012). Examining the antecedents of e-loyalty intention in an online reservation environment. The Journal of High Technology Management Research, 23(1), 46-57.

19. Zavareh, F. B., Ariff, M. S. M., Jusoh, A., Zakuan, N., Bahari, A. Z., \&Ashourian, M. (2012). E-service quality dimensions and their effects on e-customer satisfaction in internet banking services. Procedia-social and behavioral sciences, 40, 441-445.

20. Randheer, K., Al-Motawa, A. A., \& Vijay, P. J. (2011). Measuring commuters' perception on service quality using SERVQUAL in public transportation. International Journal of Marketing Studies, 3(1), 21.

21. Muthupandian, K. S., \& Vijayakumar, D. C. (2012). Measurement of passengers service quality in public transportation: servqual analysis.The Journal of Institute of Cost and Works Accountants of India

22. Huang, Y. K. (2010). The effect of airline service quality on passengers' behavioural intentions using SERVQUAL scores. Journal of the Eastern Asia Society for Transportation Studies, 8, 2330-2343.

23. Woodruff, R. B., \&Gardial, S. (1996). Know your customer: New approaches to understanding customer value and satisfaction. Wiley. 